\title{
ВПЛИВ ОКСИЕТИЛЬОВАНИХ НОНІЛФЕНОЛІВ ТА ЇХ ПОХІДНИХ НА ВМІСТ КОРТИКОТРОПІНУ, КОРТИЗОЛУ ТА АДРЕНАЛІНУ В СИРОВАТЦІ КРОВІ ЩУРІВ
}

Досліджено вплив промислових хімічних забруднювачів довкілля - оксиетильованих нонілфенолів та їх похідних у дозах 1/10 і 1/100 ДЛ50 на вміст кортикотропіну, кортизолу й адреналіну в сироватці крові щурів на 45-ту добу дії. Нонілфеноли з числом оксиетильованих груп 6, 12 та їх похідні - натрієві солі карбоксиметилатів ізононілфенолів з числом оксиетильованих груп 4, 6 у дозі 1/10 ДЛ50 знижують вміст кортизолу й адреналіну на тлі зростання рівня кортикотропіну в сироватці крові тварин, що вказує на деяке виснаження захисно-компенсаторних механізмів. Речовини в дозі 1/100 ДЛ50 підвищують рівень усіх досліджуваних гормонів, що свідчить про формування стану організму, спрямованого на збереження більш стабільних параметрів гомеостазу.

КЛЮЧОВІ СЛОВА: оксиетильовані нонілфеноли, щури, сироватка крові, кортикотропін, кортизол, адреналін.

Роботу виконано в рамках науково-дослідної роботи Харківського національного медичного університету на тему "Вивчення механізмів біологічної дії простих поліефірів у зв'язку з проблемою охорони навколишнього середовища" (номер держреєстрації 0110U001812).

ВСТУП. До розповсюджених забруднювачів довкілля відносять оксиетильовані нонілфеноли (ОЕНФ) та їх похідні - натрієві солі карбоксиметилатів оксиетильованих ізононілфенолів (КМ-ОЕНФ), які за фізико-хімічними властивостями та особливостями будови молекул належать до іоногенних детергентів. Ці речовини характеризуються досить значними об'ємами синтезу, широким використанням у різних галузях народного господарства (як основа промислового випуску пластмас, поліуретанів, мийних засобів, емульгаторів, антикорозійних препаратів, гідравлічних та охолоджувальних речовин тощо), надходженням до джерел питного водопостачання і, завдяки цьому, можливим впливом на організм людини [4, 7]. Патофізіологічні механізми дії різних груп ксенобіотиків в організмі людини та тварин останнім часом дуже інтенсивно вивчають у зв'язку зі зростанням забруднення ними навколишнього середовища [6]. Значне хімічне навантаження організму може призвести до розладів основних його регуляторних систем, сприяти масовому зростанню захворюваності,

๑ Д. І. Маракушин, 2015. генетичним порушенням та іншим змінам [2, $3,5]$. За даними більшості дослідників, на екологічну нестабільність перш за все реагують центральна нервова, ендокринна та імунна системи, викликаючи спектр функціональних розладів, порушення обміну речовин і запуск механізмів формування патологічного процесу $[1,8]$. Стан процесів нейроендокринної регуляції при тривалому впливі ОЕНФ та їх похідних вивчено недостатньо, а саме їх урахування $€$ необхідним для всебічного розкриття патофізіологічних механізмів дії та засобів їх корекції.

Метою даного дослідження було визначити в сироватці крові щурів вміст гормонів гіпофіза та надниркових залоз - кортикотропіну, кортизолу й адреналіну за умов тривалого перорального впливу оксиетильованих нонілфенолів та їх похідних у дозах 1/10 і 1/100 ДЛ50.

МЕТОДИ ДОСЛІДЖЕННЯ. У роботі ВИКОристано зразки речовин з регламентованими фізико-хімічними характеристиками: ОЕНФ з числом оксиетильованих груп 6, $12\left(\mathrm{OEH}_{6,12}\right)$ та КМ-ОЕНФ з числом оксиетильованих груп 4, 6 (КМ-ОЕНФ ${ }_{4,6}$ ). Експерименти проведено на статевозрілих щурах-самцях лінії WAG масою 180-220 г. Утримували тварин і виконували маніпуляції над ними відповідно до основних принципів у сфері біоетики. Їх піддавали пероральній затравці за допомогою зонда водними розчинами речовин щоденно одноразово 
протягом 45 діб у дозах 1/10 і 1/100 дл50. Середньолетальні дози (ДЛ50) складали: для OEHФ $-4,2$ г/Кг; ОЕНФ 12 - 3,4 г/Кг; КM-ОЕНФ 6,1 г/кг; КМ-ОЕНФ $-2,2$ г/кг маси тіла. Тваринам контрольної групи вводили відповідний об'єм питної води. Досліджували показники через 45 діб від початку експерименту. У кожній групі було по 15 щурів. Забій тварин проводили шляхом декапітації, попередньо анестезуючи тіопенталом натрію. Вміст кортизолу, кортикотропіну в сироватці крові щурів визначали методом твердофазного імуноферментного аналізу за допомогою діагностичних тестсистем "Стероид ИФА-кортизол-01" (Росія), "DSL-10-5100 Active ACTH Elisa" (США) та аналізатора імуноферментного Stat Fax 303 Plus. Концентрацію гормонів у пробах розраховували після вимірювання оптичної щільності розчинів на основі калібрувальних кривих. Адреналін у сироватці крові визначали після виділення хроматографічним методом C. Atack та ін. [9]. Елюцію адреналіну проводили із застосуванням $1 \mathrm{H} \mathrm{HCl,} \mathrm{вміст} \mathrm{оцінювали} \mathrm{на}$ спектрофлюориметрі "Hitachi MPF-4A" при довжині хвилі збудження 445 нм, люмінесценції 490 нм. Для одержання сироватки пробірки 3 кров'ю термостатували протягом 20 хв із наступним центрифугуванням протягом 10 хв при 1500 об./хв. Статистичний аналіз даних проводили з використанням комп'ютерного пакета прикладних програм для обробки статистичної інформації Statistica 6.1 (StatSoft, Inc., США). Первинне статистичне опрацювання даних починали з перевірки припущення про відповідність вибірок закону гаусівського розподілу, застосовуючи критерій Шапіро-Вілка. Додатково правильність позитивного висновку щодо нормальності розподілу вибірок контролювали за допомогою коефіцієнтів асиметрії та ексцесу. Кількісні ознаки, що мали нормальний розподіл, описували параметричними характеристиками - середнім значенням показника (M) і середнім квадратичним відхиленням (s), у разі відсутності нормального розподілу непараметричними, зокрема медіаною (Me) та інтерквартильним розмахом. Для порівняння двох нормальних розподілів застосовували t-критерій Стьюдента. Якщо принаймні один 3 розподілів не був нормальним, то для порівняння незалежних вибірок використовували критерій Манна-Уїтні. За критичний рівень значущості при перевірці статистичних гіпотез брали $\mathrm{p}<0,05$.

РЕЗУЛЬТАТИ Й ОБГОВОРЕННЯ. ЯК СвіДЧаТЬ результати дослідження, на 45-ту добу впливу ОЕНФ ${ }_{6}$, ОЕНФ ${ }_{12}$, КМ-ОЕНФ 6 та КМ-ОЕНФ ${ }_{4}$ у дозі
1/10 ДЛ50 відзначали статистично значуще ( $p<0,001)$, порівняно з контролем, збільшення рівня кортикотропіну - в середньому в 1,8 раза. Приблизно таку ж динаміку змін спостерігали і за дії дози 1/100 ДЛ50: підвищення рівня кортикотропіну становило в середньому 1,7 раза $(p<0,017)$. На цьому тлі відбувалося i зростання вмісту гормону надниркових залоз кортизолу. При використанні дози 1/10 ДЛ50 достовірним воно було тільки за дії найбільш токсичних з досліджуваних речовин ОЕНФ $\mathrm{KM}-\mathrm{OEH} \Phi_{6}-$ в 1,2 (p=0,005) та $1,4(\mathrm{p}<0,001)$ раза відповідно. При застосуванні дози 1/100 ДЛ50 рівень кортизолу підвищувався $(\mathrm{p}<0,006)$ в 1,9; 1,6; 1,3 та 1,2 раза відповідно для

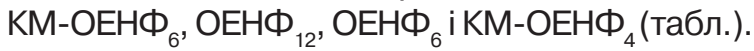

Надниркові залози як периферійна ланка гіпоталамо-гіпофізарно-наднирковозалозної системи є ендокринним ефектором адаптивної і стресреалізувальної систем, що забезпечують розвиток компенсаторно-пристосувальних реакцій та відповідь організму на різні екстремальні дії. Будь-який фізіологічний або екзогенний стресорний вплив на організм призводить до стимуляції секреції кортикотропіну і, відповідно, кортизолу, забезпечуючи тим самим адаптацію організму [10]. Тому підвищення вмісту кортикотропіну та кортизолу, особливо за умов тривалої дії ОЕНФ та їх похідних у дозі 1/10 ДЛ50, свідчить перш за все про їх участь у реалізації адаптаційних реакцій в організмі щурів. Гіперпродукування глюкокортикоїдів, як правило, викликає посилення глюконеогенезу, забезпечуючи легкодоступне джерело енергії для реакцій адаптації. Деяке зниження вмісту кортизолу при дії ОЕНФ ${ }_{12}$ та КМ-ОЕНФ ${ }_{6}$ у дозі 1/10 ДЛ50 можна пояснити послабленням стресіндукованої гіперактивації глюкокортикоїдної функції надниркових залоз та початковими ознаками зриву адаптаційно-пристосувальних реакцій в організмі експериментальних тварин.

Що стосується рівня сироваткового адреналіну, то його статистично значуще підвищення відносно контролю відмічали за дії ОЕНФ $(p=0,014)$ та $1,9(p=0,004)$ раза відповідно. Щодо ОЕНФ 12 та КМ-ОЕНФ у дозі 1/10 ДЛ50 спостерігали протилежну динаміку змін вмісту адреналіну - зниження ( $p<0,001)$ у середньому в 1,7 раза. На 45-ту добу впливу дози $1 / 100$ дл50 відзначали достовірне збільшення $(p<0,001)$ адреналіну: в 1,9 раза - для ОЕНФ 12 , в 1,8 раза - для ОЕНФ 6 та КМ-OEHФ ${ }_{4}$, в 1,4 раза - для КМ-ОЕНФ. . Зростання рівня адреналіну вказувало перш за все на мобілізацію механізмів адаптації та резистентності орга- 
Таблиця - Вміст кортикотропіну, кортизолу, адреналіну в сироватці крові щурів на 45-ту добу впливу оксиетильованих нонілфенолів та їх похідних (n=15; Me [25 \%; 75 \%] або M土s)

\begin{tabular}{|c|c|c|c|c|c|}
\hline Показник & $\mathrm{OEH} \Phi_{6}$ & $\mathrm{OEH} \Phi_{12}$ & $\mathrm{KM}-\mathrm{OEH} \Phi_{6}$ & $\mathrm{KM}-\mathrm{OEH} \Phi_{4}$ & Контроль \\
\hline \multicolumn{6}{|c|}{ Доза 1/10 ДЛ50 } \\
\hline $\begin{array}{l}\text { Кортикотропін, } \\
\text { нмоль/л }\end{array}$ & $\begin{array}{c}1124,7 \pm 299,25 \\
p<0,001\end{array}$ & $\begin{array}{c}1079 \\
{[775 ; 1221]} \\
p<0,001\end{array}$ & $\begin{array}{c}1108 \\
{[986 ; 1295]} \\
p<0,001\end{array}$ & $\begin{array}{c}968,8 \pm 116,78 \\
p<0,001\end{array}$ & $\begin{array}{c}604 \\
{[540 ; 773]}\end{array}$ \\
\hline $\begin{array}{l}\text { Кортизол, } \\
\text { нмоль/л }\end{array}$ & $\begin{array}{c}195 \\
{[170 ; 228]} \\
p=0,136\end{array}$ & $\begin{array}{c}147,8 \pm 32,02 \\
p=0,005\end{array}$ & $\begin{array}{c}127 \\
{[118 ; 149]} \\
p<0,001\end{array}$ & $\begin{array}{c}199 \\
{[177 ; 234]} \\
p=0,068\end{array}$ & $182,0 \pm 23,18$ \\
\hline $\begin{array}{l}\text { Адреналін, } \\
\text { нмоль/л }\end{array}$ & $\begin{array}{c}8,3 \\
{[6,5 ; 10,6]} \\
p=0,014\end{array}$ & $\begin{array}{r}2,9 \pm 1,07 \\
p<0,001\end{array}$ & $\begin{array}{l}3,0 \pm 0,91 \\
p<0,001\end{array}$ & $\begin{array}{r}9,3 \pm 2,36 \\
p=0,004\end{array}$ & $5,0 \pm 1,64$ \\
\hline \multicolumn{6}{|c|}{ Доза 1/100 ДЛ50 } \\
\hline $\begin{array}{l}\text { Кортикотропін, } \\
\text { нмоль/л }\end{array}$ & $\begin{array}{c}980 \\
{[800 ; 1045]} \\
p<0,001\end{array}$ & $\begin{array}{c}1116,7 \pm 93,07 \\
p<0,001\end{array}$ & $\begin{array}{c}1267 \\
{[1122 ; 1325]} \\
p<0,001 \\
\end{array}$ & $\begin{array}{c}883 \\
{[657 ; 908]} \\
p=0,017 \\
\end{array}$ & $\begin{array}{c}604 \\
{[540 ; 773]}\end{array}$ \\
\hline $\begin{array}{l}\text { Кортизол, } \\
\text { нмоль/л }\end{array}$ & $\begin{array}{c}245 \\
{[205 ; 290]} \\
p<0,001\end{array}$ & $\begin{array}{c}290 \\
{[228 ; 320]} \\
p<0,001\end{array}$ & $\begin{array}{c}345,9 \pm 67,99 \\
p<0,001\end{array}$ & $\begin{array}{c}219,9 \pm 32,70 \\
p=0,006\end{array}$ & $182,0 \pm 23,18$ \\
\hline $\begin{array}{l}\text { Адреналін, } \\
\text { нмоль/л }\end{array}$ & $\begin{array}{l}8,9 \pm 1,62 \\
p<0,001\end{array}$ & $\begin{array}{l}9,6 \pm 1,99 \\
p<0,001\end{array}$ & $\begin{array}{c}7,0[5,9 ; 9,6] \\
p<0,001\end{array}$ & $\begin{array}{l}9,0 \pm 1,84 \\
\mathrm{p}<0,001\end{array}$ & $5,0 \pm 1,64$ \\
\hline
\end{tabular}

Примітка. р - рівень значущості порівняно з контролем.

нізму експериментальних тварин у відповідь на тривалий стресовий вплив досліджуваних речовин. У свою чергу, виявлене, як і у випадку кортизолу, зниження рівня адреналіну за умов дії ОЕНФ ${ }_{12}$ та КМ-ОЕНФ в дозі 1/10 ДЛ50 свідчило про напруження адаптаційно-пристосувальних реакцій в організмі щурів.

ВИСНОВКИ. 1. У механізмі тривалої дії оксиетильованих нонілфенолів та їх похідних натрієвих солей карбоксиметилатів оксиетильованих ізононілфенолів у дозах 1/10 і 1/100 ДЛ50 на організм щурів істотною ланкою $€$ негативний вплив на процеси нейроендокринної регуляції, що підтверджується розбалансуванням гормонального профілю сироватки крові.

2. Тривала інтоксикація організму щурів оксиетильованими нонілфенолами та їх похід- ними в дозі 1/10 ДЛ50 викликає зниження вмісту кортизолу й адреналіну на тлі підвищення рівня кортикотропіну, що свідчить про формування напруженого адаптивного стану з початковими ознаками виснаження захиснокомпенсаторних механізмів.

3. Тривала дія досліджуваних речовин у дозі 1/100 ДЛ50, навпаки, супроводжується підвищенням вмісту в сироватці крові щурів кортикотропіну, кортизолу та адреналіну, що свідчить про формування стану організму, спрямованого на збереження більш стабільних параметрів гомеостазу.

Перспективи подальших досліджень. Планується провести комплекс досліджень, спрямованих на обґрунтування патофізіологічних механізмів дії оксиетильованих нонілфенолів та їх похідних, зокрема оцінку активності моноамінергічних нейромедіаторних систем головного мозку.

\section{СПИСОК ЛІТЕРАТУРИ}

1. Афанасьева А. И. Стрессы: эндокринная регуляция и фармакологическая коррекция / А. И. Афанасьева. - Барнаул : Изд-во АГАУ, 2008. - 127 с.

2. Белозерова С. М. Особенности формирования заболеваемости в условиях индустриального труда и новых технологий / С. М. Белозерова // Медицина труда и промышленная экология. 2011. - № 3. - С. 13-19.

3. Гнатейко О. 3. Екогенетичні аспекти патології людини, спричиненої впливом шкідливих факторів зовнішнього середовища / О. З. Гнатейко, Н. С. Лу- к'яненко // Здоровье ребенка. - 2007. - № 6 (9). C. $15-24$.

4. Детергенти сучасності: технологія виробництва, екологія, економіка використання / [Бурлака В. А., Руденко Г. Б., Грабар І. Г., Біба А. Д.]. Житомир : ЖДТУ, 2004. - 745 с.

5. Капранов С. В. Принципиальная схема влияния факторов среды жизнедеятельности на организм человека / С. В. Капранов // Довкілля та здоров'я. - 2011. - № 2. - С. 23-26. 
6. Ксенобіотики: накопичення, детоксикація та виведення з живих організмів / [Цудзевич Б. О., Столяр О. Б., Калініна І. В., Юкало В. Г.] - Тернопіль : Видавництво ТНТУ ім. І. Пулюя, 2012. - 384 с.

7. Научные основы обоснования прогноза потенциальной опасности детергентов в связи с регламентацией в воде водоемов / [Цыганенко А. Я., Жуков В. И., Щербань Н. Г. и др.]. - Белгород, 2001. - 442 c.

8. Татаркин А. А. Нейроиммуноэндокринные взаимодействия в системе межклеточной функциональной многоуровневой регуляции гомеостаза / А. А. Татаркин, Н. Д. Татаркина, Б. Г. Андрюков //
Здоровье. Медицинская экология. Наука. - 2010. 43, № 3. - С. 13-17.

9. Atack C. A procedure for the isolation of noradrenaline (together with adrenaline), dopamine, 5-hydroxytryptamine and histamine from the same tissue sample using a single column of strongly acidic cation exchange resin / C. Atack, T. Magnusson // Acta Ppharmacol. et Toxicol. - 1978. - 42. P. 35-57.

10. McEwen B. Physiology and neurobiology of stress and adaptation: central role of the brain / B. McEwen // Physiol. Rev. - 2007. - 87. P. 873-904.

Д. И. Маракушин ХАРЬКОВСКИЙ НАЦИОНАЛЬНЫЙ МЕДИЦИНСКИЙ УНИВЕРСИТЕТ

\title{
ВЛИЯНИЕ ОКСИЭТИЛИРОВАННЫХ НОНИЛФЕНОЛОВ И ИХ ПРОИЗВОДНЫХ НА СОДЕРЖАНИЕ КОРТИКОТРОПИНА, КОРТИЗОЛА И АДРЕНАЛИНА В СЫВОРОТКЕ КРОВИ КРЫС
}

\section{Резюме}

Исследовано влияние промышленных химических загрязнителей окружающей среды оксиэтилированных нонилфенолов и их производных в дозах 1/10 и 1/100 ДЛ50 на содержание кортикотропина, кортизола и адреналина в сыворотке крови крыс на 45-е сутки воздействия. Нонилфенолы с числом оксиэтилированных групп 6, 12 и их производные - натриевые соли карбоксиметилатов изононилфенолов с числом оксиэтилированных групп 4, 6 в дозе 1/10 ДЛ50 снижают содержание кортизола и адреналина на фоне возрастания уровня кортикотропина в сыворотке крови животных, что указывает на некоторое истощение защитно-компенсаторных механизмов. Вещества в дозе 1/100 ДЛ50 повышают уровень всех исследуемых гормонов, что свидетельствует о формировании состояния организма, направленного на сохранение более стабильных параметров гомеостаза.

КЛЮЧЕВЫЕ СЛОВА: оксиэтилированные нонилфенолы, крысы, сыворотка крови, кортикотропин, кортизол, адреналин.

\author{
D. I. Marakushin
} KHARKIV NATIONAL MEDICAL UNIVERSITY

\section{INFLUENCE OF OXYETHYLIZED NONYLPHENOLS AND THEIR DERIVATIVES ON THE CONTENT OF CORTICOTROPIN, CORTISOL AND ADRENALIN IN BLOOD SERUM OF RATS}

\section{Summary}

The influence of industrial chemical contaminants of environment - oxyethylized nonylphenols and their derivatives was investigated at doses of 1/10 and 1/100 DL50 on content of corticotropin, cortisol and adrenalin in blood serum of rats on 45th day of the influence was investigated. Nonylphenols with number of oxyethylized groups 6, 12 and their derivatives - sodium salts of carboxymethylates of oxyethylized isononylphenols with number of oxyethylized groups 4, 6 at a dose of 1/10 DL50 decrease level of cortisol and adrenalin on a background of the rise of level of corticotropin in blood serum of rats, that testifies to some exhaustion of protectively-compensatory machanisms. Substances at a dose of 1/ 100 DL50 increase level of all examined hormones, that testifies to formation of the state of the organism directed on saving of more stable parameters of homeostasis.

KEY WORDS: oxyethylized nonylphenols, rats, serum of blood, corticotropin, cortisol, adrenalin. 